\title{
Konsep Berpikir dan Dzikir sebagai Proses Pendidikan Islam
}

\author{
Asep Kurnia \\ Universitas Islam Negeri (UIN) Sunan Gunung Djati Bandung \\ E-mail: askurmirza77@gmail.com \\ Nurwadjah Ahmad EQ \\ Universitas Islam Negeri (UIN) Sunan Gunung Djati Bandung \\ Andewi Suhartini \\ Universitas Islam Negeri (UIN) Sunan Gunung Djati Bandung
}

\begin{abstract}
This research aims to examine the concept of thinking and dhikr as the process of Islamic education by using the method of literature or library research, namely research conducted through data collection or scientific papers with research objects or data collection is literature. The results of the analysis showed that, the concept of Thinking and dhikr are two activities that should not be separated. By intermediaries thinking about the universe, then comes memory as the conclusion of thinking, namely that all this does not happen by itself, but there is a God almighty creator, that is Allah SWT. Because of the real thinking, remember the more real. Islamic education is expected to change the behavior of learners, increase the knowledge of learners by channeling or transferring the concept of science and able to improve good ethics. In short, Islamic education should be able to print the ideal Muslim person as caliph.
\end{abstract}

Keywords: Dhikr, fikr, Islamic education.

\section{PENDAHULUAN}

Pada hakekatnya, tujuan seseorang mempelajari ilmu pengetahuan yaitu untuk mendekatkan diri kepada Allah Swt. dengan cara memahami hakekat ilmu secara benar. Untuk itulah, Imam al-Ghazali menegaskan bahwa ilmu pengetahuan yang hendaknya dipelajari oleh seseorang pertama kali yaitu ilmu agama (ilmu yang berhubungan dengan syariah Islam). Artinya, sebelum 
mempelajari ilmu pengetahuan yang bersifat umum (ilmu yang berkaitan dengan sains dan teknologi), seorang muslim diwajibkan memahami ilmu agama terlebih dahulu. Sebab, ilmu agama merupakan dasar dari segala ilmu. Apabila ilmu agama seseorang itu lemah maka akan lemah pula akhlaknya. Sebab, ilmu agama adalah pengontrol akhlak seseorang (Ismail, 2014:291-312).

Dalam berbagai ayat $\mathrm{Al}$-Qur'an,dijelaskanbahwa zikir dan pikir selalu berkaitan.Zikir selalu dikaitkan dengan ilmu dan para ahli ilmu.Dan konsep berzikir dalam Al Quran juga selalu berhubungandengancara berpikir manusia. Figur ulul albab yang sesungguhnya adalah pribadi yang mampu mengimplementasikan antara zikir dan fikir dalam praktik kehidupan sehari-hari sebagimana firman Allah SWT, Surah Az-Zumar ayat 9 :

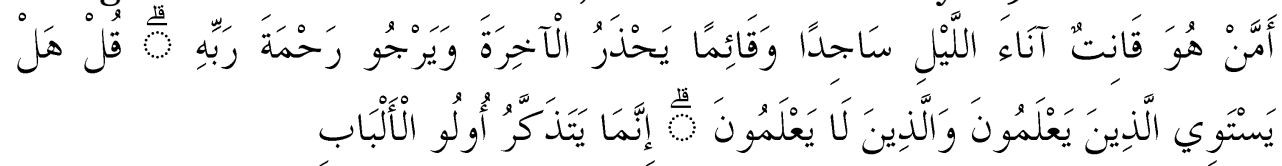

Apakah kamu orang musyrik yang lebih beruntung) ataukah orang yang beribadah pada waktu malam dengan sujud dan berdiri, karena takut kepada (azab) akhirat dan mengharapkan rahmat Tuhannya? Katakanlah, "Apakah sama orang-orang yang mengetahui dengan orang-orang yang tidak mengetahui?" Sebenarnya hanya orang yang berakal sehat yang dapat menerima pelajaran.

Ayat diatas menggambarkan begitu pentingnya berpikir dan berzikir sebab dengan hanya berpikir pengetahuan yang didapat tidak dapat menambah keimanan kepada Allah begitu pula berzikir tanpa berpikir mengakibatkan kita tidak memahami kebesaran dan keagungan Allah SWT maka konsep antara zikir dan fikir harus menyatu dan tidak boleh dipisahkan.

Dengan integrasi zikir dan pikir dalam suatu pendidikan akan efektif jika seluruh pengampu yang berkepentingan dalam pendidikan (stakeholders) sadar, yakin dan bekerjasama untuk memajukan model pendidikan yang utuh (holistik) dan terkonsep. Pendidikan adalah proses yang sistemik, tidak mungkin keberhasilan pendidikan diraih maksimal, tanpa kerjasama dan keterlibatan semua pihak.

Karena Pendidikan Islam bukanlah sekedar pembentukan manusia semata, tetapi ia juga berlandaskan Islam yang mencakup pendidikan agama, akal, kecerdasan jiwa, yaitu pembentukan manusia seutuhnya dalam rangka membentuk manusia yang berakhlak mulia sebagai tujuan utama pengutusan Nabi Muhammad SAW dalam melaksanakan perintah Allah SWT, dan 
mengenal agama secara teori dan praktis. Islam sebagai gerakan pembaharuan karakter dan sosial, dengan Nabi Muhammad SAW sebagai pembawa risalah, secara tegas telah menyatakan bahwa tugas utamanya adalah sebagai penyempurna akhlak manusia (Rofiq, 2019: 65-81).

Makalah sederhana ini akan mencoba menelaah mengenai berfikir dan dzikir sebagai proses pendidikan Islam baik secara konsep dan implementasinya. Sehingga dengan implementasi berfikir dan dzikir yang baik, maka pendidikan Islam harus mampu mencetak pribadi Muslim yang ideal sebagai khalifatullah.

\section{METODE}

Penelitian ini menggunakan pendekatan kualitatif dengan jenis penelitian kepustakaan (library research) yaitu dengan mengumpulkan data-data dan bahan-bahan yang berkaitan dengan tema pembahasannya. penelitian ini adalah subjek dari mana data tersebut diperoleh. Dalam penelitian ini yang menjadi sumber data adalah: Pertama, sumber data primer, maksudnya sumber-sumber yang memberikan data secara langsung dari tangan pertama atau merupakan sumber asli. Dalam penelitian ini yang menjadi sumber datanya berupa buku, jurnal, majalah, dll. Kedua, sumber data sekunder, yaitu sumber-sumber lain yang diperoleh dari sumber primer. Dalam penelitian ini sumber data sekunder berupa bukubuku lain yang berhubungan dengan bahasan penelitian ini. Setelah keseluruhan data terkumpul, maka langkah selanjutnya penulis menganalisa data tersebut sehingga ditarik suatu kesimpulan. Untuk memperoleh hasil yang benar dan tepat dalam menganalisa data, penulis menggunakan teknik analisis isi. Analisis isi (Content Analysis) adalah penelitian yang bersifat informasi tertulis atau tercetak di media massa.

\section{HASIL PENELITIAN DAN PEMBAHASAN}

\section{Zikir dalam Islam}

Zikir ditinjau dari segi bahasa (lughatan) atau etimologi, adalah mengingat, sedangkan secara istilah adalah membasahi lidah dengan ucapan-ucapan pujian kepada Allah. Menurut Syaikh Ahmad Fathani menjelaskan, zikir pada mulanya diartikan sebagai "bersih" (Asshafa), wadahnya adalah menyempurnakan (al-Wafa), dan syaratnya adalah hadir dihadirat-Nya (hudhur), harapannya 
adalah lahirnya amal shaleh, dan hasiatnya adalah terbukanya tirai rahasia atas kedekatan seorang hamba kepada Allah SWT (Fathoni, 2020: 98).

Kata zikir memiliki banyak arti. Menurut Sa'id ibn Jubair berkata, "Siapapun yang mematuhi Allah sebenarnya mengingat Allah". Sebagian dari para ulama terdahulu menghubungkan dengan beberapa bentuk yang lebih khusus. Imam Atha' berkata, "Perkumpulan zikir adalah perkumpulan yang didalammnya dibahas hal-hal yang haram dan halal, misalnya jual beli, shalat, puasa, perkawinan, perceraian dan ibadah haji” (Al-Sakandari, 2013:29).

Zikir adalah perpaduan seluruh gerak dan kata hati, setiap ucapan serta sikap dan perbuatan manusia, dilaksanakan dalam usahanya menjalankan peran dan fungsinya sebagai hamba Allah yang telah ditugaskan-Nya menjadi khalifah di muka bumi ini. Semua itu meliputi: (a) Mengingat, dalam hal ini adalah mengingat Allah. (b) Menyebut, dalam hal ini diantaranya adalah menyebut nama-nama Allah (Asma'ul Husna), atau kata-kata yang ada dalam Asma Allah di dalamnya, yaitu ucapan ta'awudz, basmalah, syahadat, tahlil, tahmid (al-hamdu lillah), takbir (allahu akbar), istighfar (mohon ampunan dari Allah), tarhim, tasbih. Semua ucapan tersebut disebut kalimah thayyibah, atau kalimah yang indah yang sangat dianjurkan kepada setiap mukmin untuk dibaca dan dihayati. (c) Shalat, merupakan kesatuan zikir yang terpadu meliputi hati, lisan dan gerak manusia. Ketika shalat, seseorang menghadapkan jiwa dan seluruh anggota tubuhnya. Nabi SAW bersabda, "Shalat merupakan tiang agama Islam. Barangsiapa mendirikannya berarti ia telah mendirikan agama Islam, dan barangsiapa meninggalkannya, ia telah menuntuhkan agama Islam.” (d) Membaca, mempelajari dan mengajarkan al-Qur'an dan Hadits. Dengan membaca dan mempelajari kedua sumber ajaran Islamitu, seseorang akan memperoleh sebuah pijakan dan arahan peningkatan tahap-tahap kemanusiaan hingga mencapai tingkat yang tertinggi. Penerimaan wahyu merupakan konsekuensi langsung terhadap penerimaan konsep 'aql berjenjang dalam tradisi Al-Hikmah, dengan kesadaran tertinggi kemanusiaan (al'aql al-qudsi) (Zamri, 2012: 73).

Berdasarkan beberapa pendapat tersebut, maka berzikir dengan ungkapan kata-kata tanpa rasa hudhur disebut zikir lisan, berzikir dengan merasakan kehadiran Allah dalam qalbu disebut zikir qalbu, sementara berzikir tanpa menyadari kehadiran segala sesuatu selain Allah disebut zikir sir. Itulah yang disebut dengan zikir khafiy. 
Dalam perkembangannya, zikir kepada Allah tidak hanya dibatasi sebagai bacaan-bacaan mulia tuntunan Nabi SAW (zikir ma'tsur) dalam waktu-waktu tertentu seperti diajarkan dalam kitab- kitab semacam Al-Adzkar karya Imam Nawawi, Al-Ghaniyah Syekh Abdul Qadir Jailani, Shahih al-Kalimaath Thayyib li Syekh al-Islam ibn Taimiyah-nya, Muhammad Nashiruddin Albany dan sebagainya. Namun juga, dapat diartikan sebagai "ingat Allah" dalam segala gerak tingkah laku, bahkan dalam tarikan dan hembusan nafas hamba (Kabbani, 2007: 16).

Semua orang yang merambah jalan Allah (Ahlu tharieq Allah) sepakat bahwa, zikir merupakan kunci pintu gerbang Allah dan pembuka sekat kegaiban, penarik kebaikan-kebaikan dan pelipur keterasingan. La merupakan pancaran wilayah dan pendorong kepada ma'rifat Allah, Sebab zikir tidak tergantung pada waktu dan tempat

Zikir terkadang berarti ingatan batin dan penyebutan lahir, seperti yang tercantum dalam al-Qur'an Surat al-Baqarah: 152.

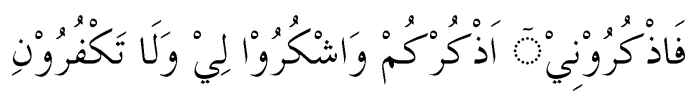

"Karena itu, ingatlah kamu kepada-Ku niscaya Aku ingat (pula) kepadamu, dan bersyukurlah kepada-Ku, dan janganlah kamu mengingkari (nikmat)-Ku"

Dengan zikir yang ma'tsur dari Rasulullah SAW. seperti dapat dipelajari dari semisal kitab-kitab, maka akan bisa membuat seorang hamba jika mengamalkan secara benar tidak sempat berpaling dari Khaliqnya. Bayangkan, tuntunan zikir itu mencakup zikir sejak bangun tidur hingga akan tidur lagi.

Namun barangkali masalahnya justru kesibukan manusia modern dan kepintarannyalah yang lambat laun membuat zikir ma'tsur itu seolah-olah terlupakan. Dalam proses pembelajaran di sekolah ataupun di perguran tinggi sekalipun banyak yang lalai dari mengingat Allah padahal ilmu yang dipelajarai adalah milik Allah SWT seyogyanya harus mengembalikan itu semua tertuju kepada Allah yang memiliki semua ilmu yang ada di langit dan dibumi karna tanpa penghayatan dan pengingatan kepadanya.

Hakikat zikir ialah kehadiran hati yang hendaknya dijadikan tujuan utama bagi pelakunya yaitu harus berusaha keras untuk merealisasikannya, memikirkan makna zikir yang dibacanya, dan memahami maknanya. Memikirkan makna zikir ketika sedang melakukannya merupakan hal yang dianjurkan, sebagaimana 
dianjurkan pula ketika sedang membaca al-Quran. Mengingat keduanya mempunyai tujuan yang sama karena itu menurut pendapat yang shahih dan terpilih, orang yang berzikir disunatkan memanjangkan ucapannya dalam mengucapkan Laa Ilaaha Ila Allah (tidak ada Tuhan selain Allah). Dikatakan demikian karena didalamnya terkandung kesempatan untuk memikirkan maknanya; pendapat ulama Salaf dan ulama Khalaf mengenai hal ini telah masyhur (Nawawi, 2016: 22).

Menurut Imam al-Ghazali, hakikat zikir adalah berkuasanya Allah didalam qalbu disertai kesucian zikir itu sendiri. Namun, dalam pandangannya, zikir memiliki tiga kulit atau lapisan yang salah satunya lebih dekat kepada inti (lubb) daripada yang lainnya. Inti (lubb) tersebut berada di balik tiga kulit tadi. Kulit-kulit itu adalah sebagai jalan menuju inti (lubb). Kulit yang paling luar adalah zikir lisan semata. Setiap zikir memiliki pengaruh tertentu. Zikir yang disertai kesiapan akan bisa membuka tirai, tetapi hal itu disesuaikan dengan kondisi orang yang melakukannya. Sedangkan Imam Al-Maraghi dalam tafsirnya menjelaskan tentang QS. alAhzab: 41-42 bahwa hakikat zikir harus dengan hati, lidah, serta anggota tubuh dengan zikir yang banyak dalam segala keadaan sekuat tenaga. Karena Dialah yang memberi nikmat kepadamu dengan bermacam-macam kenikmatan dan bermacam-macam anugrah (Maraghi, 2017:28).

\section{Konsep Pikir dalam Islam}

Berpikir ialah gejala jiwa yang dapat menetapkan hubunganhubungan antara pengetahuan-pengetahuan manusia. Berpikir merupakan suatu proses dialektis, artinya selama manusia berpikir, pikiran tersebut mengadakan tanya jawab pikiran. Untuk dapat meletakkan hubungan-hubungan antara pengetahuan manusia dengan tepat.

Dalam al-Khawathir, Syekh Muhammad Mutawalli alSyarawi mengatakan, pikiran adalah alat ukur yang digunakan manusia untuk memilih sesuatu yang dinilai lebih baik dan lebih menjamin masa depan diri dan keluarganya. Dengan berpikir menurut James Allan, seseorang bisa menentukan pilihannya. Dalam psikologi sosial. Ilmuwan, mendifinisikan "berpikir" sebagai bagian terpenting yang membedakan manusia dari binatang, tumbuhan dan benda mati. Dengan berpikir, manusia bisa membedakan yang bermanfaat dan tidak bermanfaat, antara halal dan haram, antara yang positif dan yang negatif. Dengan begitu,ia bisa memilih yang cocok bagi dirinya dan bertanggung jawab atas pilihannya (Elfiki, 2013:3). 
Berpikir merupakan keterampilan beroperasinya tindakan kecerdasan dan pengalaman. Ia lebih tertarik pada kegunaan mengembangkan ide-ide daripada membuktikan efektifitas dan keandalan pendekatannya. Alat berpikir secara ekspilit dirancanf dengan relevansi praktis dan memudahkan komunikasi sebagai atribut aktif." (Kuswana, 2012:186)

Otak dan tubuh terintegrasi kuat oleh sirkuit biokimia dan sirkuit saraf secara timbal balik. Ada dua rute utama interkoneksi ini. Rute utama biasanya dianggap tersusun dari saraf-saraf tepi sensoris dan motoris yang membawa sinyal-sinyal dari setiap bagian tubuh ke otak, dan dari otak ke setiap bagian tubuh. Rute lain, yang biasanya mudah dibayangkan meski justru inilah bentuk evolusi yang lebih tua, adalah aliran darah, membawa sinyal kimia seperti berbagai hormon, neutrotransmiter, dan modulatormodulator.

Akal sebagai sumber ilmu yang kedua, memainkan peranan yang sangat esensial dalam melengkapi segala kekurangan yang diderita oleh panca indra manusia. Akal menurut filosof muslim merupakan kecakapan jiwa/mental yang khas manusia karena tidak ada hewan apapun yang memilikinya.Kekuatan yang khas yang dimiliki akal menurut para filosofi adalah kemampuan untuk mengabstrak dari konsep-konsep universal yang sudah diabstrak dari benda-benda konkrit sehingga ia mempu berpikir sesuatu yang sama sekali tidak memiliki sangkutan dengan benda-benda fisik. Kemampuan akal untuk mengabstrak ini jelas merupakan sumber ilmu yang melimpah karena ia bisa mengenali esensi dari segala apa pun yang ia temui didalam semesta yang luas ini (Kartanegara, 2005:107).

Kemampuan akal untuk mengenal atau menangkap konsep dan informasi tidak terbatas hanya pada objek-objek indrawi, karena akal dapat juga menangkap konsep-konsep abstrak yang tidak berdasar pada pengindraan. Misalnya akal mampu memahami perasaan seseorang, seperti perasaan sedih,gembira,kecewa dan sebagainya, padahal itu bukan entitasentitas fisik melainkan keadaan-keadaan jiwa (Sab’in, 1978:64-79).

Al-Ghazali dalam kitabnya, Miskat al-Anwar, ia banyak menjelaskan bahwa kelebihan akal dibanding dengan mata adalah bahwa akal dapat melihat dimensi batin dan rahasia sesuatu,melihat hakikat mereka dan jiwa-jiwa mereka (Al-Ghazali, 1998:6-7).

Ada tiga macam keterampilan-keterampilan berpikir yang 
perlu dikuasai individu, mencakup:

a. Keterampilan berpikir kritis, termasuk menaganalisis, mengkritisi, memutuskan, mengevaluasi, membandingkan, dan menaksir.

b. Keterampilan berpikir kreatif, termasuk menciptakan, menemukan, membayangkan, memprakirakan, dan hipotesis.

c. Keterampilan berpikir praktis, dilibatkan ketika kecerdasan diperlukan pada konteks dunia nyata dan bergantung pada pengetahuan yang tersimpan, tetapi bukan hasil pembelajaran formal.

Tiga aspek tersebut mengandung isi kecerdasan untuk mencapai keberhasilan, dan merupakan gambaran kemampuan untuk encapai keberhasilan dalam hidup, cita-cita pribadi, sesuai dengan konteks sosial budaya. Kemampuan untuk mencapai keberhasilan bergantung pada penggunaan catatan dari kekuatan koreksi, kelemahan, sehingga terjadi keseimbangan antara analisis, kreativitas, dan praktis, kemampuan penyesuaian diri dengan bentuk memilih lingkungan (Kuswana, 2012:165)

Dengan demikian, pendekatan berpikir kritis melibatkan ranah kognitif, afektif, dan konatif. Dia menempatakan karyanya setara Ennis, Paulus, dan Lipman. Akan tetapi ia juga mengklaim beberapa aspek yang berbeda berdasarkan penekanannya pada peran sumber daya intelektual dan kebutuhan memasukkan berpikir kritis kekurikulum.

\section{Implementasi Konsep Zikir dan Pikir Sebagai poses Pendidikan Islam}

Manusia dikaruniai 'aql oleh Allah agar digunakan untuk berpikir dan merasa. Banyak ayat al-Qur'an yang mengisyaratkan hal ini. Allah sering kali menginstruksikan kepada manusia untuk berpikir. Dari telaah terhadap berbagai kata yang digunakan oleh al-Qur' an dapat direkam makna bahwa manusia adalah makhluk Allah yang diberi perangkat oleh Allah, yang dengan perangkat itu manusia mampu berpikir dan merasa. Jika manusia tidak mempunyai kemampuan berpikir dan merasa pasti Allah tidak akan menginstruksikan kepada manusia untuk berpikir dan merasa. Manusia berpikir dengan rasionya dan dengan berpikir itu manusia menghasilkan ilmu dan teknologi. Manusia merasa dengan hatinya dan disinilah iman bersemi.

Pendidikan merupakan fitrah manusia yang harus dipenuhi. Karena sebagai fitrah, pendidikan harus senantiasa disesuaikan dengan fitrah kemanusiaan yang hakiki yakni menyangkut aspek 
material dan spiritual, aspek keilmuan sekaligus moral, aspek duniawi sekaligus ukhrawi. Pendidikan diharapkan dapat merubah tingkah laku peserta didik, menambah pengetahuan peserta didik dengan menyalurkan atau mentrasnfer konsep ilmu pengetahuan serta mampu meningkatkan budi pekerti yang baik. Pendek kata, pendidikan Islam harus mampu mencetak pribadi Muslim ideal sebagai 'abdullah sekaligus khalifatullah. Manusia mempunyai kewajiban untuk beribadah dan menjalankan apa yang diperintahkan Tuhan dan meninggalkan segala larangan-Nya. Manusia juga berkewajiban menjaga dan melestarikan kekayaan alam yang memang disediakan untuk kepentingan manusia (Ismail, 2020:325).

Pendidikan mempunyai tugas untuk mengembangkan kedua aspek tersebut. Dengan kata lain pendidikan mempunyai misi untuk mengembangkan pikiran dan perasaan manusia dengan baik dan wajar. Tentunya pendidikan juga tidak melupakan bahwa unsur jasmaniah ada dalam kawasan garapannya amal saleh, ilmu dan iman dimanifestasikan secara lahiriah. Banyak ayat-ayat al Qur'an yang mengajak manusia untuk bertafakkur dan bertadzakkur. Tadzakur dan tafakkur merupakan dua hal yang sama-sama berpangkal pada akal. Walaupun sama-sama bersumber dari akal, tetapi antara tafakkur dan tadzakur itu berbeda. Tafakkur dilaksanakan untuk menghasilkan pengetahuan yang baru, sedangkan tadzakkur dilaksanakan untuk mengungkapkan kembali informasi dan pengetahuan yang telah didapatkan sebelumnya, yang terlupa atau terlalaikan. Pada hakikatnya kita sudah mengetahui akan keberadaan Allah SWT, akan tetapi kita sering kali lalai ataupun lupa kepada- Nya. Melalui tadzakkur manusia berusaha untuk mengingat akan kehadiranNya.

Hasil Pendidikan Barat yang kita saksikan sekarang ini adalah bergesernya manusia dari makhluk teosentris menjadi makhluk materialis. Ini sebagai akibat dari humanisme ateis yang disuarakan oleh Renaisans. Dengan penemuan manusia dalam bidang ilmu dan teknologi, manusia merasa menjadi superman. Namun tidak dapat dipungkiri, banyak hal yang tidak dapat dipecahkan dan dijawab oleh kreativitas otak manusia. Hal ini disebabkan oleh paradigma dan epistimologi yang mereka gunakan jauh dari nuansa spiritual transendental. Pendidikan Barat mengembangkan materialisme yang meyakini bahwa realitas kehidupan manusia hanyalah materi. Dampaknya, manusia 
menjadikan materi sebagai titik sentral. Salah satu akibatnya adalah semakin subur budaya materialistik hedonistik yang menjebol akar spiritual dalam kehidupan manusia dewasa ini dan hal ini sangat mengkhawatirkan kehidupan umat manusia. Pendidikan yang hanya mementingkan materi tidak diterima bahkan ditolak oleh Pendidikan Islam, sebab menurut konsep Islam, manusia terdiri dari aspek jasmani (materi) dan aspek ruhani (non- materi) yang keduanya harus mendapat porsi untuk dikembangkan. Al-Qur'an dan al- sunnah berkali-kali memberi pesan kepada orang tua (pendidik utama) untuk menjaga anaknya dengan sebaik- baiknya dan jangan menelantarkannya (Anis, 2008: 69-85).

Abududdin Nata dalam bukunya yang berjudul 'Tafsir AyatAyat Pendidikan"yang menjelaskan tentang posisi akal dan kedudukannya dalam pendidikan Islam. Orang yang berakal (Ulul Albab) adalah orang yang memiliki dua hal yaitu tazakkur (mengingat Allah SWT), dan tafakkur (memikirkan ciptaan Allah SWT). Dengan melakukan dua hal tersebut ia akan sampai kepada hikmah yang berada dibalik proses tazakkur (mengingat) dan tafakkur (berpikir) yaitu mengetahui, memahami, dan menghayati bahwa dibalik fenomena alam dan segala sesuatu yang ada didalamnya menunjukkan adanya sang Pencipta.

Objek dari tafakkur adalah makhluk-makhluk Allah SWT yang berupa alam semesta, sedangkan objek dari tadzakkur adalah Allah SWT. Semakin banyak hasil yang diperoleh dari pikir dan dzikir maka semakin luas pengetahuan tentang alam raya dan semakin dalam pula rasa takut kepada Allah SWT. Hal ini tercermin dari tercermin pada permohonan agar supaya dihindarkan dari siksa api neraka. Fikir dan dzikir merupakan dua kegiatan yang tidak boleh dipisahkan. Dengan perantara memikirkan alam raya, maka timbullah ingatan sebagai kesimpulan dari berpikir, yaitu bahwa semua ini tidaklah terjadi dengan sendirinya, melainkan ada Tuhan yang Maha Penciptanya, itulah Allah SWT. Oleh karena memikirkan yang nyata, teringatlah kepada yang lebih nyata.

Dzikir mempunyai efek pendekatan diri pribadi kepada Allah SWT yang mengandung arti penginsanan diri akan makna hidupnya, yaitu makna hidup yang berpangkal dari kenyataan bahwa kita berasal dari Tuhan dan akan kembali kepada- Nya. Dengan demikian setidak-tidaknya manusia mempunyai pembenteng diri dari kemungkinan tergelincir kepada kejahatan. Sedangkan fikir sebagai gandengannya merupakan hal yang tidak kalah penting karena setelah manusia menggunakan potensi berpikirnya dengan benar, maka ilmu pengetahuan yang akan 
mereka dapatkan dan itu akan menjadi bekal mereka dalam melaksanakan tugas sebagai khalifah di bumi dalam rangka menjaga kelestarian dan memanfaatkan apa yang telah Allah SWT ciptakan untuk manusia.

Menurut Ahmad Tafsir, manusia sebagai ciptaan Allah diberi tugas menjadi hamba dan khalifah di bumi. Allah memberikan tugas tersebut kepada manusia dengan membekali manusia unsurunsur yang sama pentingnya, yaitu unsur akal, jasmani dan rohani. Ketiga unsur ini dapat dikembangkan oleh manusia sesuai dengan minat dan bakatnya, tentunya dalam melaksanakan tugasnya di bumi.

Materi pendidikan Islam harus meliputi tiga aspek tersebut. Materi pertama yaitu materi pendidikan jasmani. pemeliharaan kebersihan dan kesehatan terhadap semua anggota badan merupakan wujud nyata dari pendidikan jasmani. Anak didik harus memiliki ilmu pengetahuan yang dapat menghantarkannya pada kesadaran akan pentingnya kebersihan dan kesehatan. Materi kedua yaitu materi pendidikan akal. Potensi akal merupakan potensi yang sangat urgen pada diri seseorang karena itu, anak didik membutuhkan beberapa materi ilmu pengetahuan agar mampu berfungsi sebagaimana mestinya. Materi ketiga, pendidikan hati (qalb). Potensi hati pada anak didik menjadi perhatian penting dalam pendidikan Islam karena salah satu tujuan dari pendidikan Islam itu sendiri adalah untuk menghidupkan hati, membangun dan menyuburkannya.

\section{SIMPULAN}

Simpulan akhir dari kajian ini bahwa, konsep Fikir dan dzikir merupakan dua kegiatan yang tidak boleh dipisahkan. Dengan perantara memikirkan alam raya, maka timbullah ingatan sebagai kesimpulan dari berpikir, yaitu bahwa semua ini tidaklah terjadi dengan sendirinya, melainkan ada Tuhan yang Maha Penciptanya, itulah Allah SWT. Oleh karena memikirkan yang nyata, teringatlah kepada yang lebih nyata. pendidikan Islam diharapkan dapat merubah tingkah laku peserta didik, menambah pengetahuan peserta didik dengan menyalurkan atau mentrasnfer konsep ilmu pengetahuan serta mampu meningkatkan budi pekerti yang baik. Pendek kata, pendidikan Islam harus mampu mencetak pribadi Muslim ideal sebagai khalifatullah. 


\section{DAFTAR PUSTAKA}

A. Fathoni, Dzikir dan Fikir, Nusa tenggara Barat: Forum Pemuda Aswaja, 2020.

Aby Muhammad Zamri, Rahasia Energi Zikir, Bandung: Marja, 2012

Al-Ghazali,The Niche of Light (Al-Miskat al-Anwar), terjemah David Buchman Proco Utah: Brigham Young University Press,1998

Al-Maraghi, Tafsir Al-Maraghi, Terjemah Tafsir Al-Maraghi, Jilid 22, $\mathrm{Tt}$

Ibn Sab'in, Budd al-A'rif, Beirut: Dar Al-Andalus \& Dar Al-Kindi, 1978

Ibnu At-Thaillah al-Sakandari, Zikir Penentram Hati, Jakarta: Zaman, 2013

Ibrahim Elfiki "Quwwat al-Tafkir" oleh penerjemah Khalifurrahman Fath \& M. Taufik Damas, Terapi Berpikir Positif, Jakarta: Zaman, 2013

Imam Nawawi, Khasiat Zikir dan Doa, terjemahan Al-Adzkaarun Nawawiah Bandung: Sinar Baru Algensindo, 2016

Mohammad Ismail, "Konsep Berpikir Dalam Al-Qur'an dan Implikasinya Terhadap Pendidikan Akhlak," Ta'dib 19, no. 02 (2014): 291-312.

Muh. Anis, "Manusia Dalam Perspektif Al-Qur'an (Kajian Kependidikan)," Jurnal Kependidikan Islam 3, no. 2 (2008): $69-85$.

Muhammad Husnur Rofiq, "Model Pembentukan Karakter Berbasis Tasawuf Akhlaqi," Jurnal Ilmuna 1, no. 2 (2019): 65-81.

Mulyadi Kartanegara, Integrasi Ilmu sebuah rekonstruksi Holistik, Bandung: PT. Mizan Pustaka, 2005

Rudin Haryono, "Integrasi Akal (Pikir) Dan Spiritual (Dzikir) Dalam q.s. Ali 'imron Ayat190-191 Dan Implementasinya Dalam Pendidikan Islam

Salahudin Ismail, Implikasi konsep fikir dan dzikir dalam pendidikan Islam, Jurnal Risalah vol 6 no 2 September 2020. hal 325.

Syekh Muhammad Hisam Kabbani, Energi Zikir dan Solawat, Jakarta: Serambi Ilmu Semesta, 2007

Wowo Sunaryo Kuswana, Taksonomi Kognitif Perkembangan Ragam Berpikir, Bandung: PT Rosda Karya 